\title{
3 The life of objects
}

This extraordinary object (Fig. 3.1), usually called a cult drum, comes from a place in Sweden, Balkåkra, north of the town of Svarte in Scania, where it was pulled out of a bog in 1847 (Knape \& Nordström 1994). Made of bronze, it consists of an openwork frame of ten sections riveted together, pierced by thirty holes and surmounted by ten wheel-like rings on the upper rim. Along with it there was a flat bronze disc of the same diameter as the bronze frame, decorated with zig-zags, and presumed to fit into the base of the drum. Nothing else like it is known from Scandinavia; it was soon realised that the object is close in form and technique to the metalwork of the Bronze Age Carpathian Basin. This similarity was confirmed when in 1913/14 a very similar object was found in a sand pit at Haschendorf or Hasfalva near Sopron (Ödenburg), just on the Austrian side of the border with Hungary (Gömöri \& Kaus 2014; Bünker 1914; Kaus \& Kaus 2012). This object, while not in the centre of Carpathian Basin bronze production, is at least close to it, and less surprising in terms of location - even if its form and function remain mysterious.

Both these objects are remarkable, both for their workmanship and for their form (and thus their potential meaning). But the Swedish piece is all the more extraordinary in that it came into the ground so far from its presumed area of

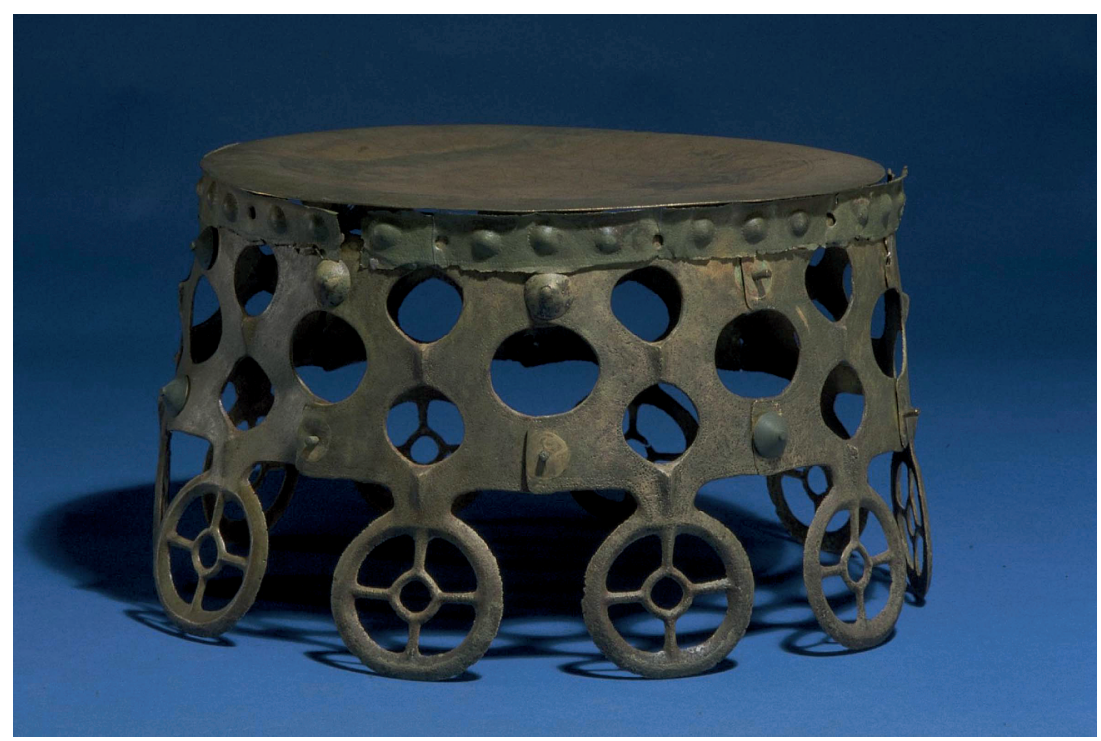

Fig. 3.1: The cult “drum” from Balkåkra, Scania, Sweden. Photo: Swedish History Museum.

Ә OpenAccess. (c) 2021 Harding, published by De Gruyter. (cc) BY-NC-ND This work is licensed under the Creative Commons Attribution-NonCommercial-NoDerivatives 4.0 License.

https://doi.org/10.1515/9783110705805-004 
production, $1000 \mathrm{~km}$ or more, the journey from workshop to findplace including a considerable sea crossing. How did this object get from central Europe to Scandinavia, and perhaps more important, why?

These are questions we cannot answer with any certainty, but we can suggest some. Since the objects are not utilitarian in nature, they were presumably connected with performances of some kind, whether cultic, musical, or magical - or all three. The Balkåkra drum must have had a life that extended far beyond the narrow confines of the workshop and settlement where it was made. Like all objects, ancient or modern, its life can be described through a personal history, what some have referred to as its biography. A number of authors have used this approach; in European prehistory one of the first was Robin Skeates with his 1995 study of Neolithic and Bronze Age axe-amulets in Italy and Malta (Skeates 1995).

Most archaeological objects are not as unusual as these. The normal expectation, when you visit a museum, has been to find artefacts sitting in cases, mute, little more than collections of particles, formed into their present shape a long time ago, and for that reason presumed to be of interest and importance. What can we say about an object like the storage vessel shown in Fig. 3.2? We suppose that it once fulfilled a certain function, in this case storage of foodstuffs, and therefore had a presence in a Bronze Age house; it has been reconstructed, so it was found in a fragmentary condition. What more? Not much. It sits in a small regional museum and attracts little attention from the few visitors who come past; as a pot it probably only attracted specific attention in the Bronze Age when it was first installed and then when it broke. In Fig. 3.3 is another pot, in this case a well-known one, with a design of a pair of wheeled vehicles pulled by horses incised on it (Vizdal 1972). That immediately marks it out as unusual and special; but what else can we say? In this case the pot is complete, so it may have been carefully kept, curated, and regarded as different. Now it is an object of interest to scholars, perhaps a curiosity to lay museum visitors. But it too had a life and a history; how can we use that approach to assist in building up a picture of the period from which it emanates?

\section{Object biographies}

Much has been written in recent years about objects and their role in the life of people (Kopytoff 1986; Hoskins 1998; 2006; Gosden \& Marshall 1999; Holtorf 2002; Joy 2009; Burström 2014; Boschung et al. 2015). It has become a popular trope that an object has a life history, a biography, which can be reconstructed and placed in the service of our study of the ancient past. It is of course possible 


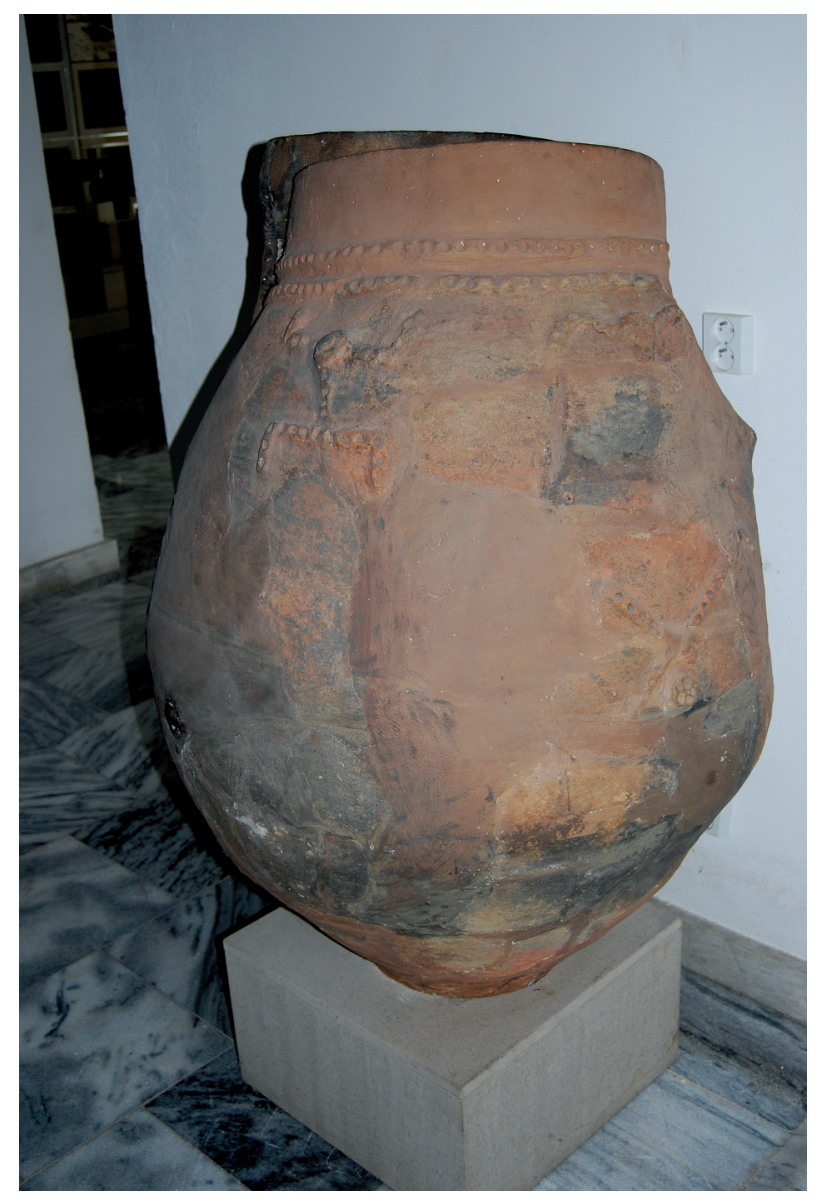

Fig. 3.2: Bronze Age storage vessel in the Vlastivedné Múzeum Trebišov. Photo: author.

in some instances to reconstruct at least some of the stages in the life history of an object, and perhaps to relate them to what humans, individuals or groups, were engaged in. It is obvious that things are created by people, less so that they create people - in the sense that their very existence determines how people behave towards them. It would be tedious and unnecessary to labour the point; but it applies as much to the Bronze Age as to any other period.

We can apply this approach to any object. I owe to Albert Dietz, at the time one of the doctoral students attending the seminar course I led in Munich, the example of the horses of St Mark's in Venice (Freeman 2004) (Fig. 3.4) to illustrate how objects have a history - and of course changing meanings for those who possessed or viewed them over the years. It is well known that these copper 


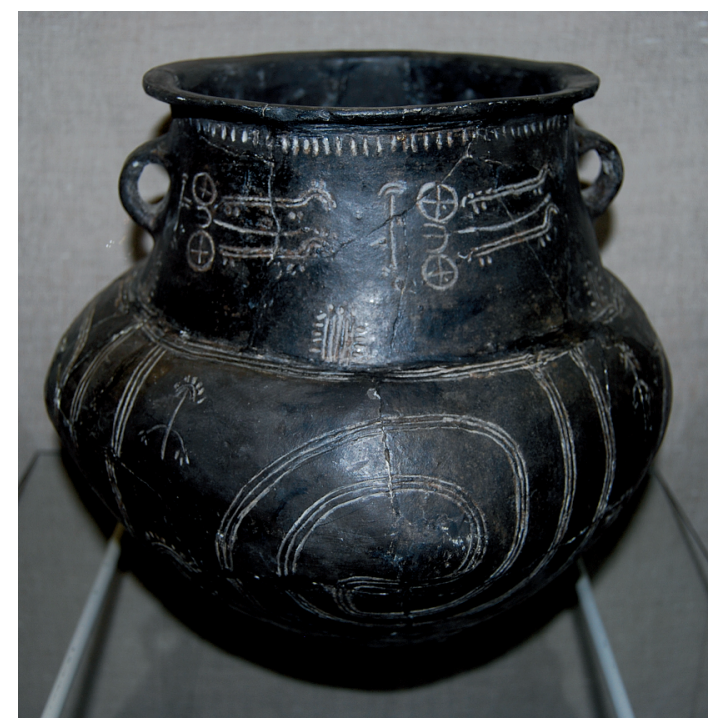

Fig. 3.3: Vessel with depiction of two-wheeled vehicle drawn by horses, from Vel'ké Raškovce, district Trebišov, in Zemplínské Múzeum, Michalovce. Photo: author.

alloy objects were made in classical antiquity, most likely Roman work of the second century AD; they may have been on the island of Chios at one time, but what is certain is that they were taken to Constantinople and displayed, with the quadriga of which they were part, in the Hippodrome, one of the glories of that great city even through its declining years. In 1204, when the city was sacked by the Venetians during the Fourth Crusade, the horses were removed as booty, subsequently brought to Venice under the instructions of Doge Enrico Dandolo, and erected on the terrace of the loggia of the church in 1254. There they remained until 1797 when Napoleon, as part of his dismantling of the Venetian Republic, had them taken to Paris, where they adorned the Arc de Triomphe. In 1815, after Napoleon's defeat at Waterloo, they were taken back to Venice and reinstated at St Mark's (though a replica was created for the Arc de Triomphe). In 1980 they were removed as part of a conservation programme, and replaced by copies; the originals, after conservation, can now be seen in the museum section of the visit to St Mark's. The collars on the horses were added when they were erected at St Mark's, to disguise the join between head and body (or, according to another version, the break happened when the heads were removed to facilitate their transport to Venice).

These objects, or we should probably say "this object", in that the quadriga was conceived as a single piece of art, thus has a history of several very distinct 


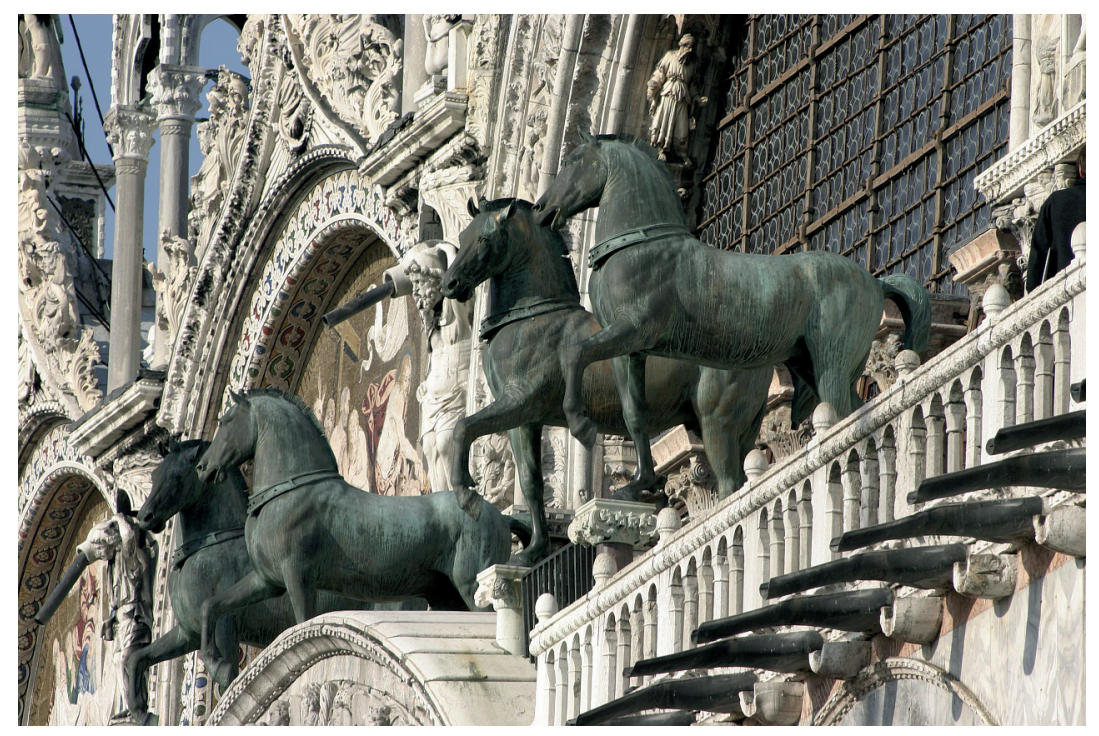

Fig. 3.4: The horses of St Mark's, Venice (reproductions on the cathedral façade). Photo: Nino Barbieri, Creative Commons licence.

phases, though what unites them is the high quality and high status of the piece as an art work, leading to its desirability for people in many different contexts. The person who made it was an artist, presumably fulfilling an order from patrons who wanted a magnificent display object which would reflect well on both themselves and on the location and city for which they were intended, wherever that was. The same motive presumably determined the removal to Constantinople several centuries later, to adorn a public building, perhaps a different one from that for which it was originally intended. For the Venetians the original significance had been lost; they were prized as booty of the highest quality. The display on the loggia of St Mark's was a statement of the power and glory of both the church and the city; the church was of course provided with other magnificent objects brought from elsewhere, above all the Pala d'Oro, the porphyry statue of the Four Tetrarchs, and especially the bones supposed to be those of St Mark, brought from Alexandria in 828 and rediscovered in a pillar in 1094. So the horses now had nothing to do with their original function, or horse racing - or, for that matter, with Christianity. They were a symbol of the power and glory that was Venice.

Napoleon's removal of them was part symbolic, in that he brought the Venetian Republic to an end and removal of one of its most famous objects acted as a metaphor for the loss of power, and part again a statement of power, epitomised 
by the placement on the Arc de Triomphe. Again, it has nothing to do with the original function.

Finally, after the restoration to Venice, the object re-acquires something of its original symbolism (though not all, since Venice was no longer the powerhouse it was, and was becoming what it is today, a tourist destination). And now the horses have become yet another thing: a museum object, the subject of the visitor's gaze, the gaze usually brief and uninformed, before the viewer takes person, smart-phone and selfie stick to the next attraction. In the meantime, the horses have been part of the conservator's daily work, yet another function, an object from the ancient past needing to be restored.

So these extraordinary objects have had a long and varied life, which continues today. We could write a biography of them, and of the people and places they have influenced. Several authors have considered such matters in the context of ancient depositions and redepositions (e.g. Bradley \& Williams 1998; Bradley 2002; Knight et al. 2019). For Knight and colleagues, the horses of St Mark's would come under the category of "reappropriated, reused and recycled objects" (Knight et al. 2019, 11); an excellent analogy is provided by the "Hammer of St Martin”, a Bronze Age axehead of stone mounted in a medieval silver-plated wooden haft and assuming a Christian function in the medieval Netherlands; subsequently it travelled around the country as an object of veneration (Knight et al. 2019, 1-2). Other examples have been cited by these and other authors.

Let me turn now to the Bronze Age, and objects that come from it. First, swords. I have long found these weapons interesting, not for typological reasons but because of their potential for informing us about an important aspect of life: aggression and combat, whether by individuals or groups (see Chapter 5). Some pieces have a history that has more than a little to tell us.

My first example is one that I studied over 30 years ago, in a small museum in Croatia (Harding 1995, 34 no. 73, Taf. 11) (Fig. 3.5). It comes from a place called Rumin, near Bitelić, district of Sinj, and was bought in 1980, part of an old collection. Only the grip and upper blade are preserved, but that is enough to be able to attribute it to a class, what I called the Marina type, datable to the main period of hoard deposition in central and eastern Europe, equivalent to Ha A1 in Germany. The interesting thing about this piece is that it was repaired in antiquity: the midrib of the blade was sawn across, the ribs filed away and a rivet inserted; this was hammered to fill the missing part of the ribs. The repair then broke again. And finally, the sword must have been broken into its present state prior to eventual deposition, probably with other fragmentary bronze objects (information which is unfortunately not available). Why did this rather ordinary sword undergo so many changes in its lifetime? What was its special importance that led to such unusual treatment? 


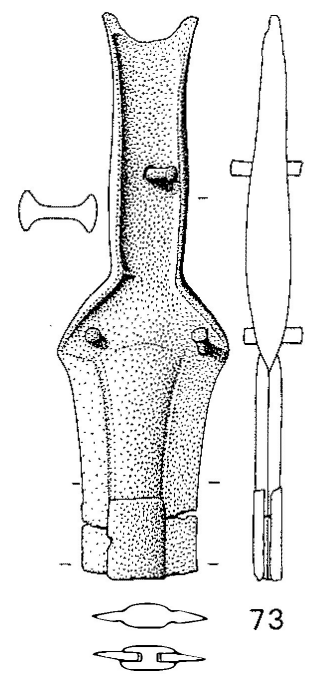

Fig. 3.5: Fragmentary sword from Rumin, Croatia, showing ancient repairs. Source: Harding 1995.

Another special sword is that from the Romanian site of Perşinari, Dîmboviţa county, near the town of Tîrgovişte (Fig. 3.6), an extraordinary gold weapon, with ribs that follow the outline of the curving blade. The hilt end is broken, which makes an accurate assessment of its original form, and thus affinities, difficult. Nevertheless, a series of scholars have gone on record as saying that this is a piece with close affinities to Mycenaean weapons, if not actually of Mycenaean manufacture (Bader 1991, who bluntly calls it Mycenaean; Alexandrescu 1966, who does not list the piece in her catalogue of Romanian swords, let alone as a Mycenaean piece), partly because of the curving ribs, but also because of the gold - though this in fact makes it unique. Twenty years ago, however, Alexandru Vulpe showed that the original form of the sword was quite different, and nothing like any known Mycenaean sword (Vulpe 1995). X-radiography showed that originally it had a rounded heel with two small rivets, obviously to attach a hilt or handle; subsequently it was modified by the addition of the hilt we see today. Vulpe made a case that the original intention was not to create a sword at all but a halberd (a dagger mounted at right-angles to its hilt) or an axe, similar to the gold axes found in the Măcin hoard. This is not very convincing, but what is clear is that the original intention was to make something rather different from what we have today. Again, this is a life history in several stages; and in this case a rather special one, since the weapon was made in gold - something even the Minoans and Mycenaeans did not do, for all their fondness of the metal. Add to this the fact that goldsmithing requires a somewhat different set of skills from bronzesmithing, and the differences are complete. 


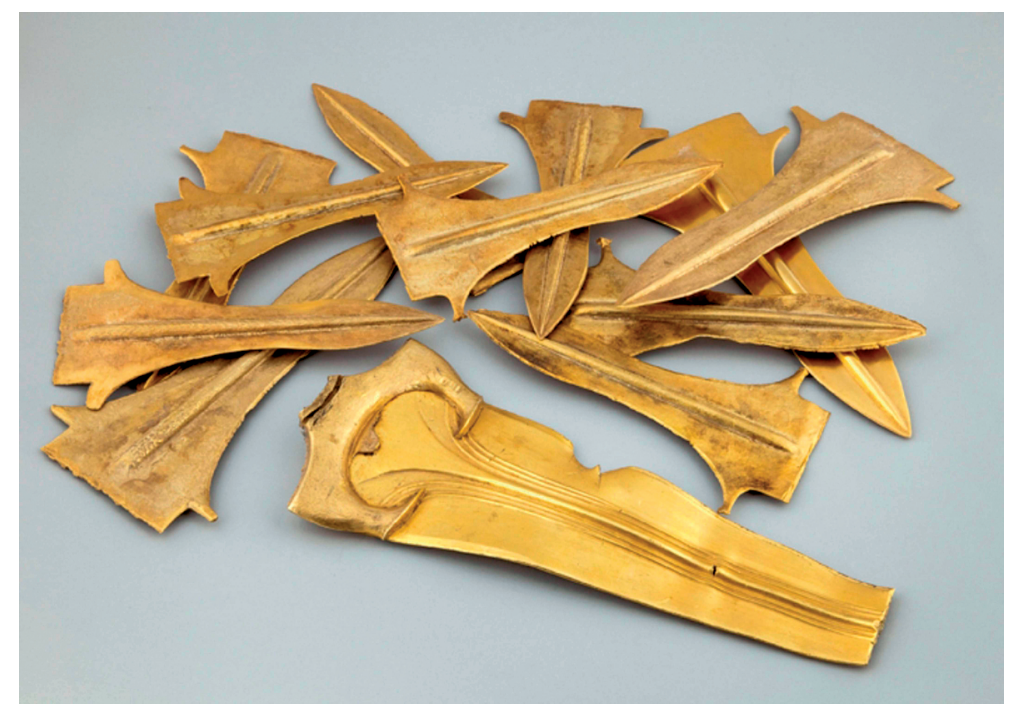

Fig. 3.6: The Perşinari hoard with gold sword. Photo: National History Museum of Romania.

In fact this piece joins a few others from south-east Europe and Anatolia that form an unusual group of weapons without any clear parallels elsewhere. A recent find from north-east Bulgaria, now in the Varna Museum (Fig. 3.7) (Athanassov et al. 2009), shows clear similarities; and the discovery of an unusual sword at Boğazköy, some distance outside the citadel on the south-west side, is also similar in some respects (Fig. 3.8) (Ünal et al. 1990-91; Hansen 1994a). This last piece is very interesting: from its form we can say that it is not an Anatolian weapon, and though it has similarities to Mycenaean swords it is not a typical example of those either.

The life of this last piece bears especial mention, since it bears an inscription in Akkadian: "As Duthaliya the Great King shattered the Aššuwa country, he dedicated these swords to the Storm-God, his lord". The king is question is presumed to be Tudhaliyas II who reigned in the fifteenth century BC (dating depends on the chronology preferred), and the ravaging of the Aššuwa country must refer to his campaign there, known from the Annals of Tudhaliya. The precise location of Aššuwa is not known, other than that it must have been in northwest Anatolia, inland from Troy. But the addition of such an inscription to a weapon of non-local origin makes this a sword with a real significance through its presumed history (not that we know what that history was). It is not the only such piece: a sword of Naue II type, now in Berlin and allegedly from Tell Firaun in the Nile Delta, has a cartouche of the pharaoh Seti II stamped onto its blade 

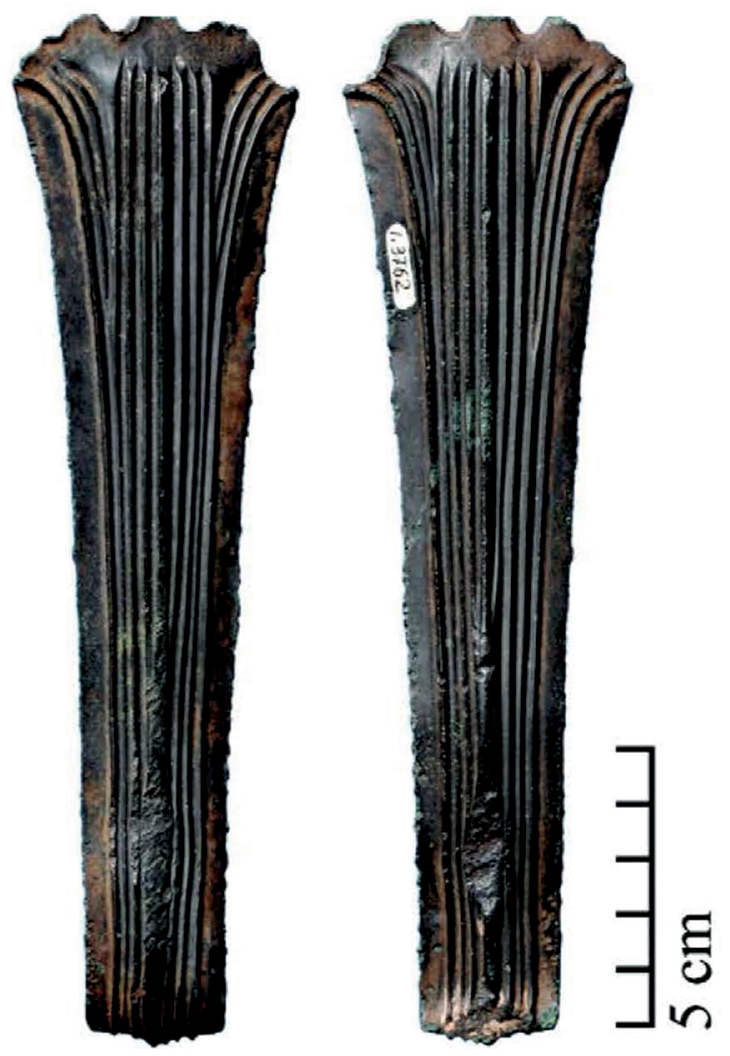

Fig. 3.7: Sword from north-east Bulgaria in Varna Museum. Source: Athanassov et al. 2009.

(Bietak \& Jung 2007-08); a similar phenomenon, though not on a European sword, is known from Ugarit, bearing the cartouche of Merneptah (Jung \& Mehofer 2005-6 (2008)) (Schaeffer 1956, 172 Fig. 124) (Fig. 3.9). The Egyptian piece is a European form of sword par excellence; it is remarkable enough that such a piece found its way to Egypt at all, but for it then to be Egyptianised is more remarkable still.

In all these cases we might assume that these are swords which had a life, perhaps a name - as with Notung or Hrunting or Hrotti or Excalibur - and a history based on the warriors who wielded it and the enemies they slew with it. Mark Pearce has suggested (Pearce 2013) that the same is true for those La Tène swords which have names stamped on them, and perhaps too for spearheads with exotic decoration of concentric circles that can be interpreted as 


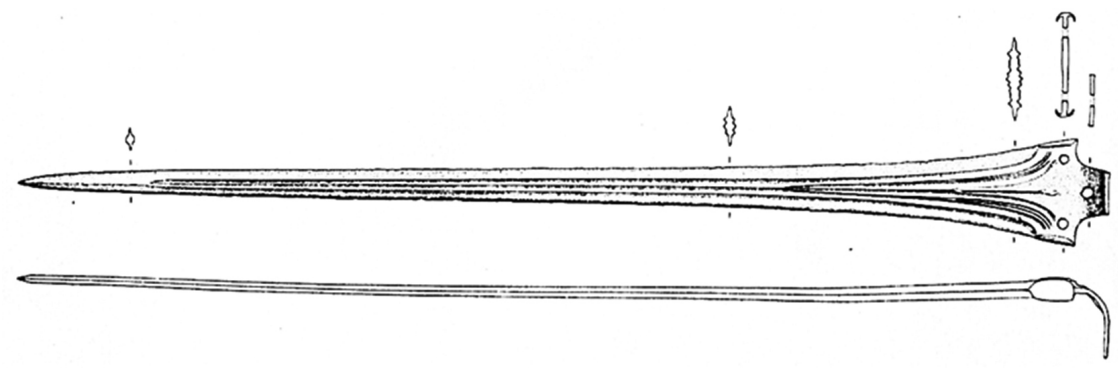

Fig. 3.8: Sword from Boğazköy bearing an Akkadian inscription. Source: Ünal et al. 1990-91.

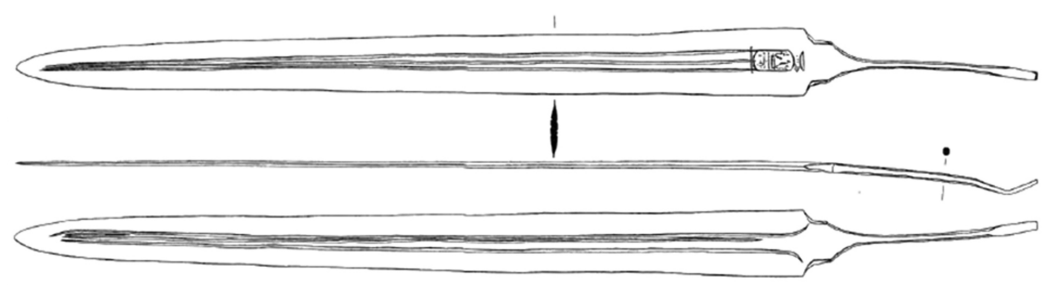

Fig. 3.9: Sword from Ugarit bearing the cartouche of Merneptah. Source: Jung \& Mehofer 2005-6.

faces (Fig. 3.10). Are these some kind of representations of individual people? Or merely generic?

It would not be appropriate for me to discuss the Nebra disc, given the amount of attention which it has received in both scholarly and popular literature, but I do want to stress that this too has a complicated biography. Four main phases are recognisable in its creation (Meller 2010, 48 Abb. 10) (the fifth in the published image represents later damage), excluding the damage caused when it was illegally removed from the ground. First the disc with sun, moon and stars was created. In the second and third phases the boat and the so-called horizons were added, as can be seen from the cramped space that was formed by the addition of the boat, while adding the horizons necessitated the removal of some of the stars (it is not quite certain in which order these two events fall). Finally a series of holes was punched into the outer edge, presumably for attaching the disc to something. We do not know how long these processes took; the only dating evidence comes from the swords which were said to accompany the disc and which can be dated to the mid second millennium $\mathrm{BC}$, perhaps around 1600; a single radiocarbon date on a tiny piece of birch bark adhering to the disc is consistent with this. 


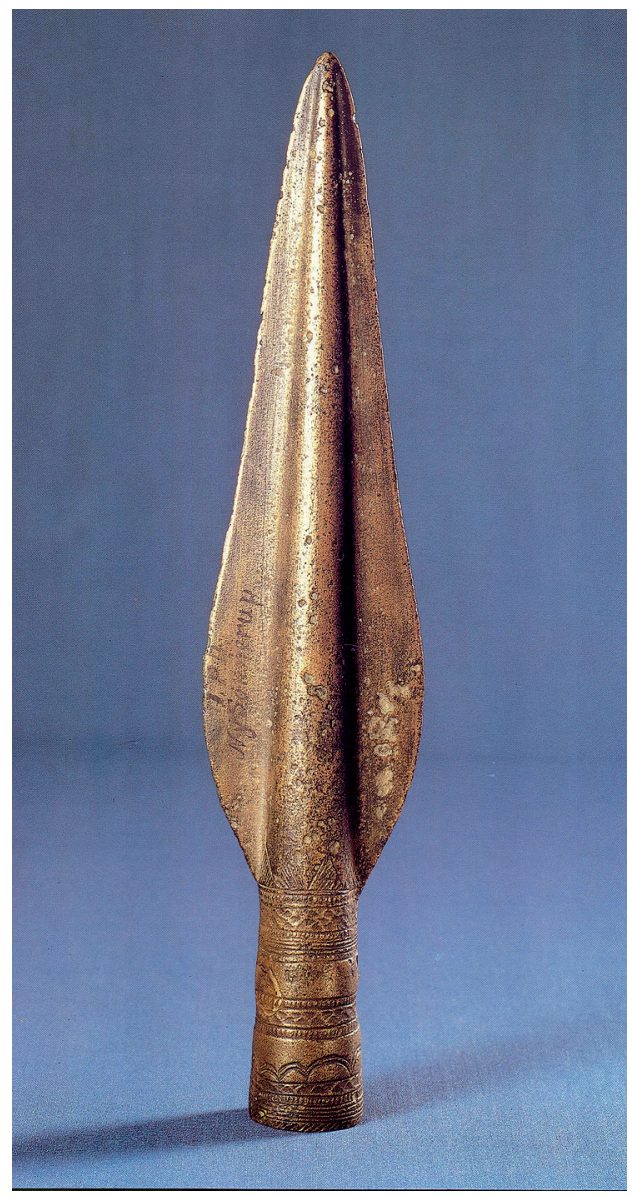

Fig. 3.10: Bronze spearhead with decoration, perhaps indicating the personal characteristics or identity of the weapon. Source: Abbaye de Daoulas 1988.

The point about all this is that the disc had an original function, presumably as some kind of astronomical device or depiction (different theories have been advanced). This continued, in modified form, in the second and third phases, and it may have existed still in the last phase, in spite of the iconoclastic approach which those who punched the holes adopted - though it is more likely, in my opinion, that by this stage it was no more than a decorative piece, to be looked at but not used. 


\section{Objects of personal use}

So far I have talked about those objects where we can clearly see a change over time. But not everything underwent such a change, even when it travelled far from its place of manufacture. The travel of objects is full of potential for our interpretation of the past. Turning to swords again, it is clear that these weapons travelled, presumably with warriors. There are swords of genuine Mycenaean type found in North Macedonia and Kosovo (Harding 1995, 20 - 23 nos 23-25 Taf. 4) (Fig. 3.11). The one on the left is an absolutely typical Mycenaean horned sword, of Sandars type C (Sandars 1963); it has been given special treatment, as only a few of the class have, by having spiral ornament added below the shoulders - and this is not in the Argolid where one might expect such things, but in distant Macedonia. The one on the right is too damaged to be sure exactly what its original form was, but one thing is clear: it has been rehafted, in other words, it has a history. It was found in a grave, so its owner must have died in an area outside the Mycenaean zone. Was he (or she) a travelling warrior? We should remember also that a standard Mycenaean sword was found in the cargo of the Uluburun ship (Pulak 1988, 21-2 Fig. 21), along with weapons of Italian type (Yalçin et al. 2005, 621); and a Naue II sword was in the cargo of the Cape Gelidonya ship (Bass 2013; not found in the earlier campaigns: Bass 1967). This may be useful for telling us something about where that ship had travelled, though it is rather harder to say whether those on board were merely traders, or something more.

Here is another example. On the right (Fig. 3.12) are more swords, from the far west, Britain. All are examples of the antenna sword, which was at home in central Europe and Italy, as is well known. The left-hand example came from the River Witham in Lincolnshire, eastern England, one of the hundreds of bronzes dredged out of rivers in Britain (as in many other countries, including Germany) (Colquhoun \& Burgess 1988, 122 no. 751 pl. 111). ${ }^{1}$ What are these swords doing so far from their place of manufacture? Presumably the intact examples were carried there by warriors; maybe mercenaries, maybe travellers carrying their weaponry with them, for a show of prowess or simply for safety's sake. How then did the sword end up in a river? That brings us to a much-discussed topic, the reasons for the deposition of so much Bronze Age metalwork in places where it could not have been retrieved. With just one object we are not on strong ground; but there are plenty of cases where many pieces were found close together in river beds. As an example, a group of swords was found in the Elbe at the

1 On this reference, see Note on page 131. 

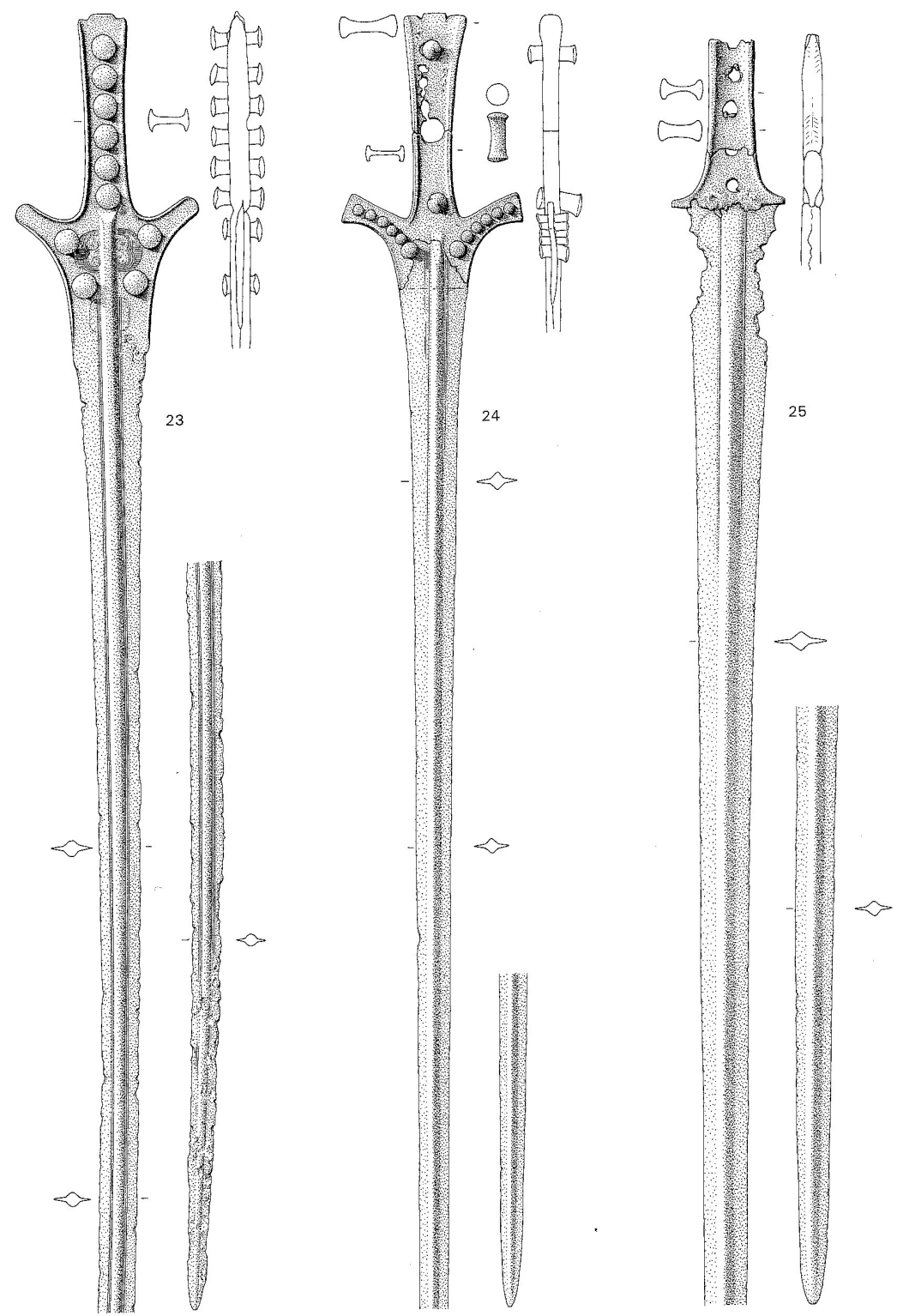

Fig. 3.11: Swords of Mycenaean type from North Macedonia and Kosovo. Source: Harding 1995. 
Porta Bohemica (Velké Žernoseky) in northern Bohemia (Fig. 3.13) (Plesl 1961 Pl. 54); we may compare the group of fourteen shields deposited in a bog at Fröslunda (Fig. 3.14) (Hagberg 1988), on the southern side of Lake Vänern, central Sweden. These have sometimes been considered to be the weaponry of a defeated foe, thrown away in an act of symbolic defiance and destruction. Maybe the swords are the same.

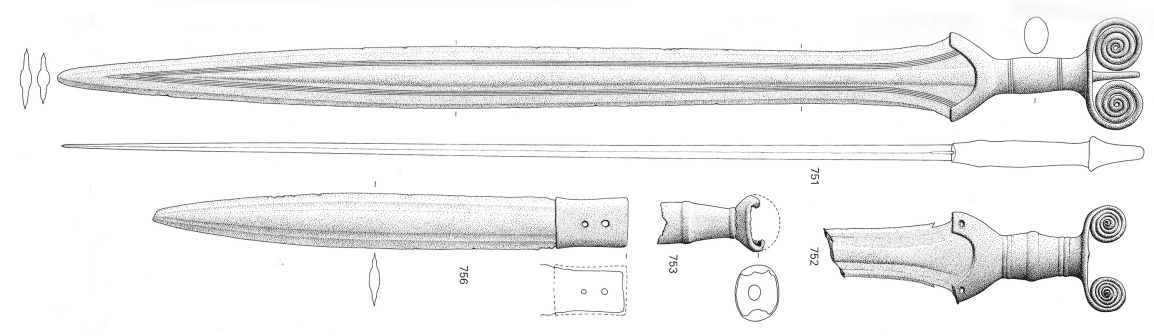

Fig. 3.12: Antenna swords from Britain. Source: Colquhoun and Burgess 1988.

The point about all this is that each object has a history, sometimes obscure, sometimes reconstructable. We could say the same for each one of the hundreds of thousands of bronzes that have survived from the Bronze Age, in theory also for the millions of pots - but that is a step too far for this short discussion.

Turning to other items of personal use, one can hardly do better than refer to the work of Ulrike Wels-Weyrauch, who charted the regional variations in female dress in the Tumulus Bronze Age so effectively (Wels-Weyrauch 1989); this enabled Albrecht Jockenhövel to write his much-cited article on Fremde Frauen (Jockenhövel 1991), in which individual items from one area are found in the territory of another, the suggestion being that women were moving in marriage between communities. One can do something similar with razors for men. A distribution map like those published by Jockenhövel shows rather clearly that there are specific areas where particular razor types appear (Jockenhövel 1980) (Fig. 3.15). Since razors were personal items, probably carried around by individuals, such a distribution strongly suggests that men (one presumes men) moved between different community areas, their razors accompanying them to the grave when they died. Of course razors can potentially tell us something else: whether or not men shaved (Harding 2008). This is something we can chart with some probability, since razors became very common during the course of the Bronze Age - though not in every part of Europe. In the Minoan-Mycenaean world the frequent occurrence of razor-knives, along with the depiction of men as cleanshaven, shows us that shaving was the norm there (the bearded figure on the 


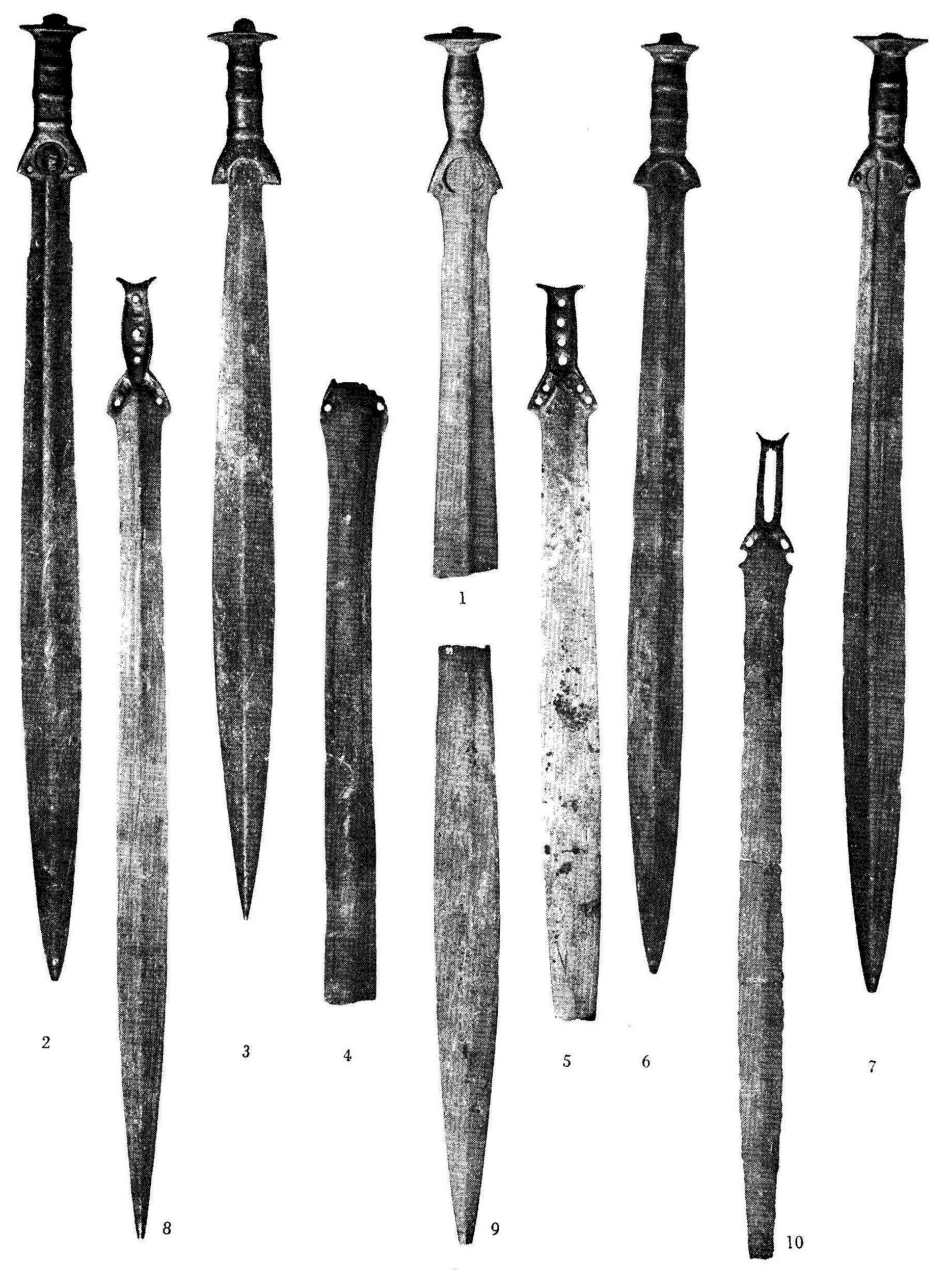

Fig. 3.13: Swords from the river Labe (Elbe) at Porta Bohemica, Velké Žernoseky, Czech Republic. Source: Plesl 1961.

gold mask from Shaft Grave V is an exception). In most of central Europe there are numerous razors, but in the British Isles hardly any (though a few more are turning up through the Portable Antiquities Scheme). This I suppose confirms the widespread impression in Europe, still prevalent, that those in the far West were savage barbarians who didn't know how to behave or dress properly, let alone produce edible cooking.

We should also mention other items of personal equipment, for instance tweezers and combs, commonly found in Late Bronze Age graves, as in the fa- 


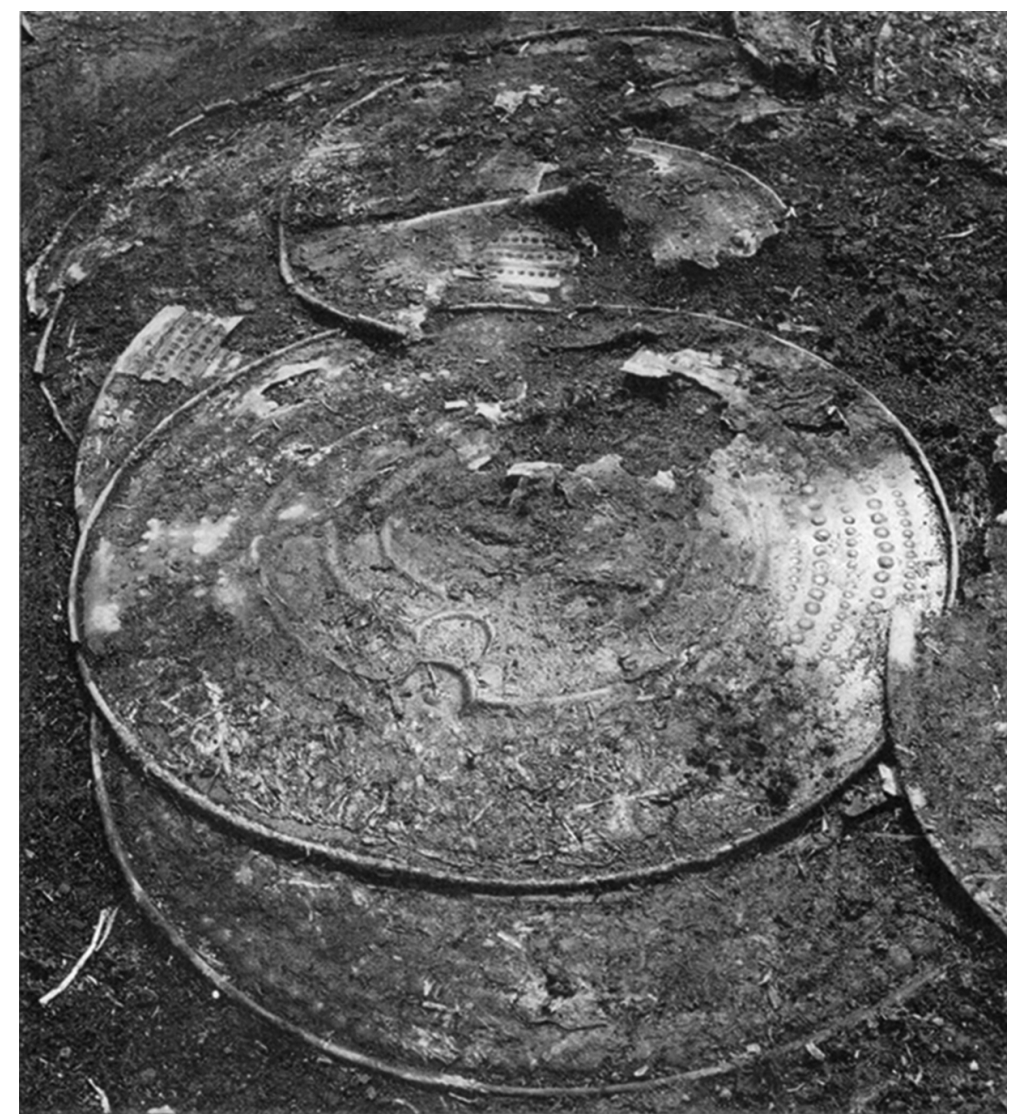

Fig. 3.14: Shields from Fröslunda, central Sweden, as discovered. Source: Hagberg 1988.

mous Seddin grave (Metzner-Nebelsick 1997; Kiekebusch 1928; May \& Hauptmann 2012). Another item that may have been used in this context is the awl, which many people over the years have suggested was used for tattooing, as was the case with Ötzi (Samadelli et al. 2015). In this context, I should mention the work of Janet Spector, whose article of 1991 "What this awl means" was fundamental in producing a reassessment of the role of women in preliterate societies (Spector 1991). The awl in question, or rather the metal point and decorated awl handle, were compared with ethnographic accounts which related how young women, at the time of their first menstrual cycle, would be taken to a separate teepee where their mothers would teach them the art of quill embroidery and moccasin making. Spector followed this with a narrative of life in a Dakota village in which the use of the awl plays a significant role (Spector 1993). Her 


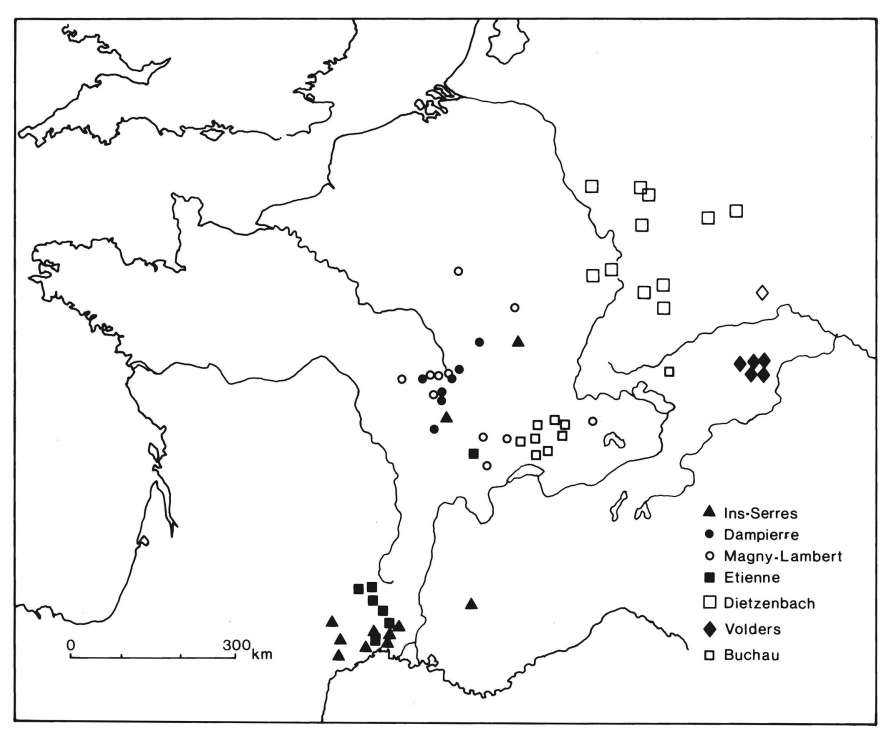

Fig. 3.15: Distribution of certain razor types, indicating specific areas where particular types were at home. After Jockenhövel 1980.

work has been followed by several authors, including (in a Bronze Age context) Mark Pearce, who attempted something similar for early metal-using groups in northern Italy, concentrating on the use of awls for tattooing (Pearce 2000).

One could follow a similar line of reasoning with other objects, for instance the axe, which clearly had a highly significant role in many prehistoric cultures. Although for us the axe is a tool used in carpentry or tree-felling, its use as an object of much wider significance in prehistory is clear. Even if we leave out the double axes that occur frequently in East Mediterranean cultures, the axe appears on rock art in the West from the Neolithic onwards (for instance in the Kilmartin area of Scotland and, most famously, at Stonehenge, probably in the Beaker period). The transformation of the axe as a forestry tool to an object used in fighting - real or ceremonial - has been charted by several authors (e.g. Chapman 1999b). Its appearance as the so-called battle-axe represents the culmination of this process; such objects cannot realistically have been used in battle but rather as the insignia of those who might have been regarded as fighters. In the full Bronze Age, outsize axes, usually called "cult axes" in Scandinavia, are a continuation of this process (e.g. Broholm 1944-5, Pl. 28,5; 
J. Jensen in Hvass \& Storgaard 1993, 155), ${ }^{2}$ just as the outsize daggers of Ommerschans type found in Britain, France and the Netherlands (Butler \& Bakker 1961; Needham 1990) are a manifestation of the same thing in weaponry (Fig. 3.16).

\section{Destruction and fragmentation}

I turn now to a related but distinct matter: the question of whether objects were deliberately destroyed or broken, why, and what the consequences of that wilful destruction might have been. Observers have long been aware that many objects found archaeologically, and not just prehistoric ones, were deposited incomplete or damaged, with no sign of the missing parts and no obvious motive for the deposition when a quick bit of mending would have been possible. The study of fragmentation in archaeology owes a great deal to the work of John Chapman, notably in a couple of influential books (Chapman 1999a; Chapman \& Gaydarska 2007). The basic idea is that it is not coincidental that so many objects are broken and incomplete; while post-depositional disturbance might account for some such breakage, there are many cases where it is unlikely to apply. That means that such objects were intentionally broken and intentionally deposited in different places - if they are present at all (if not they must have been taken off site and discarded elsewhere, thrown into the river, or something similar). In this view, nothing was a matter of chance. Chapman went on from this starting point to suggest that after intentional breakage, pieces of object would be given to other people in a process known as enchainment, the creation of a linkage between individuals, related to but not the same as gift-giving. While I do not go as far as Chapman does, since I believe that there is much we do not understand about site destruction over the centuries, I can see that in many cases this thesis is a plausible one. His work with Bisserka Gaydarska has concentrated on Balkan Neolithic and Eneolithic figurines, which as is well known are usually incomplete. Refitting figurines on certain sites, notably Dolnoslav, south-east of Plovdiv in Bulgaria, have shown that at least some of these figurines have pieces found in different houses (Chapman \& Gaydarska 2007, Chapter 6). Their study showed a total of 52 refits out of a total of 484 figurine fragments, to form 25 joining pieces. These authors considered this quite a high proportion, but one must remember that the majority cannot be reconstructed; the missing bits are simply

2 Recent finds include Early Bronze Age examples from Boest, near Nørre Snede, Jutland: http://sciencenordic.com/five-massive-bronze-age-axes-unearthed-denmark, accessed 14 August 2018. 


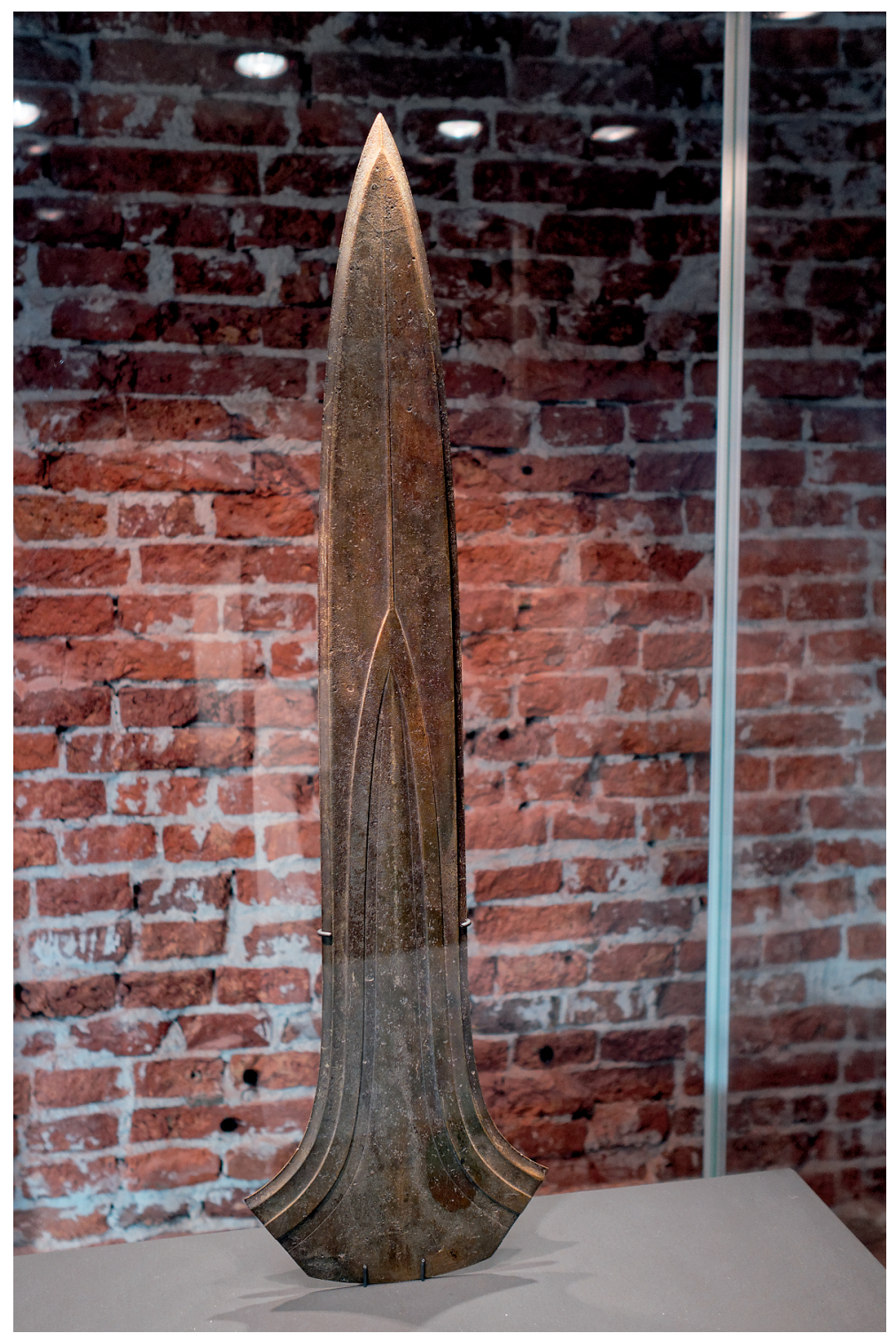

Fig. 3.16: The oversize sword from Ommerschans, Overijssel (Netherlands). Photo: Eric de Redelijkheid, Creative Commons licence.

absent - and this is a particularly important site because the later phase, belonging to the Late Eneolithic, has been almost completely excavated. 
Since Chapman started these exercises, a series of others have followed. These have been concerned particularly with pottery, a procedure which in fact has a much longer history - though not as long as stone refitting. Thus a student of the late Lawrence Barfield conducted a refitting exercise for the Neolithic site of Rocca di Rivoli (Dalla Riva 2003), and other studies have been done on Hungarian Neolithic and medieval sites. What, one may well ask, about bronzes? Here we enter an area that has long intrigued archaeologists who work on the Bronze Age, because of the very large number of hoard finds containing broken objects. Early attempts to apply the idea to Bronze Age hoards were those by Peter Turk (Turk 1997; 2001), who convincingly demonstrated that certain axe types seem deliberately to have been broken prior to deposition. To discuss the reasons for hoarding would mean another book; this is well-trodden ground. If we ignore those hoards that consist largely of perfect objects, and turn our attention simply to those containing broken pieces, often in large numbers and usually containing many different types, we have many examples to choose from. A typical case is that of a hoard found by metal detectorists in a field at Ainderby Steeple in north-east England, consisting of 114 bronze objects and containing a typical selection of fragmentary swords and spearheads, axes, rings, and other small pieces. The usual explanation for such collections has been that they are scrap metal awaiting remelting and recasting, but though this seems an obvious solution which it is tempting to adopt, there are serious objections to it - not least the fact that so many such hoards were never recovered, which would be strange if metal was in the high demand we suppose. What is more, the selection seems deliberate, not random, as several scholars have pointed out, in a range of different geographical contexts (Hansen 1994b; Willroth 1985; Maraszek 1998). Now, add to that this curious discovery: two joining pieces of the same sword found $3 \mathrm{~km}$ apart on two different low hills either side of the River Trent in Staffordshire, central England (Bradley \& Ford 2004) (Fig. 3.17). Extraordinary as this is, it actually fits with what we are coming to understand about the motivation behind the deposition of metal in the Bronze Age: it was part of a much more deliberate process than we have believed; and deliberate in a way that is hard for us to comprehend.

Matthew Knight, in a doctoral dissertation from Exeter University, has worked on this very question of destruction (Knight 2017 (published 2019); 2018; 2019). He has created a set of protocols to determine whether and how an object was intentionally destroyed. That is proving to be quite a challenge, since one usually does not know how an object got broken, and how to separate those that might have been broken in use, or for purely practical reasons (like reuse in a casting), or for ritual or cultic reasons. As part of this work, Knight has created a set of replica Bronze Age objects which he then set about breaking, or 


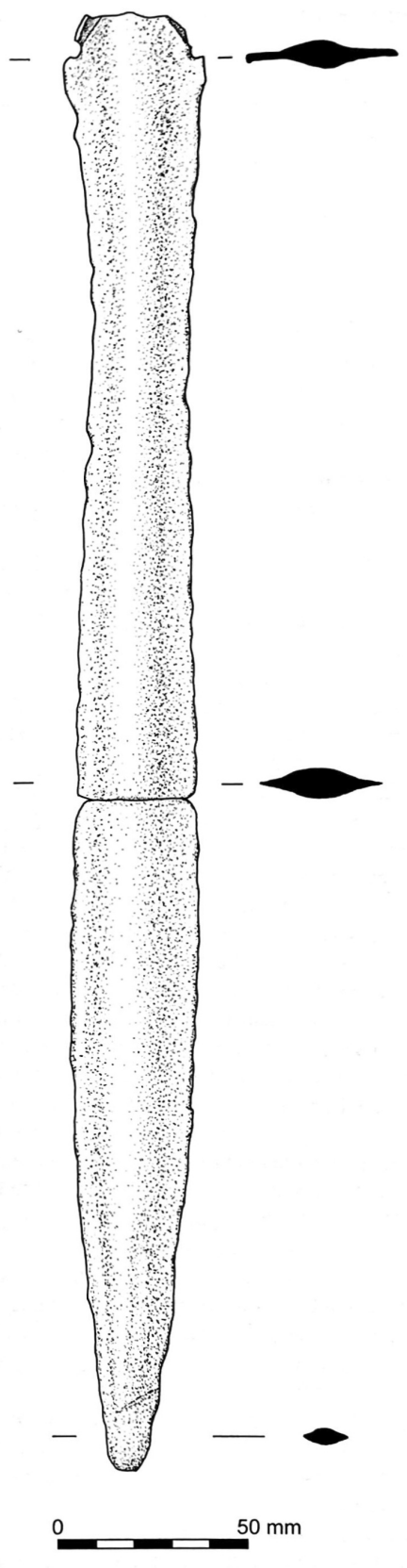

Fig. 3.17: Two fragments of the same sword, from sites on different sides of the River Trent, Staffordshire. Source: Bradley \& Ford 2004. 
trying to break, so as to examine the fracture patterns and general shape after manipulation (Fig. 3.18).

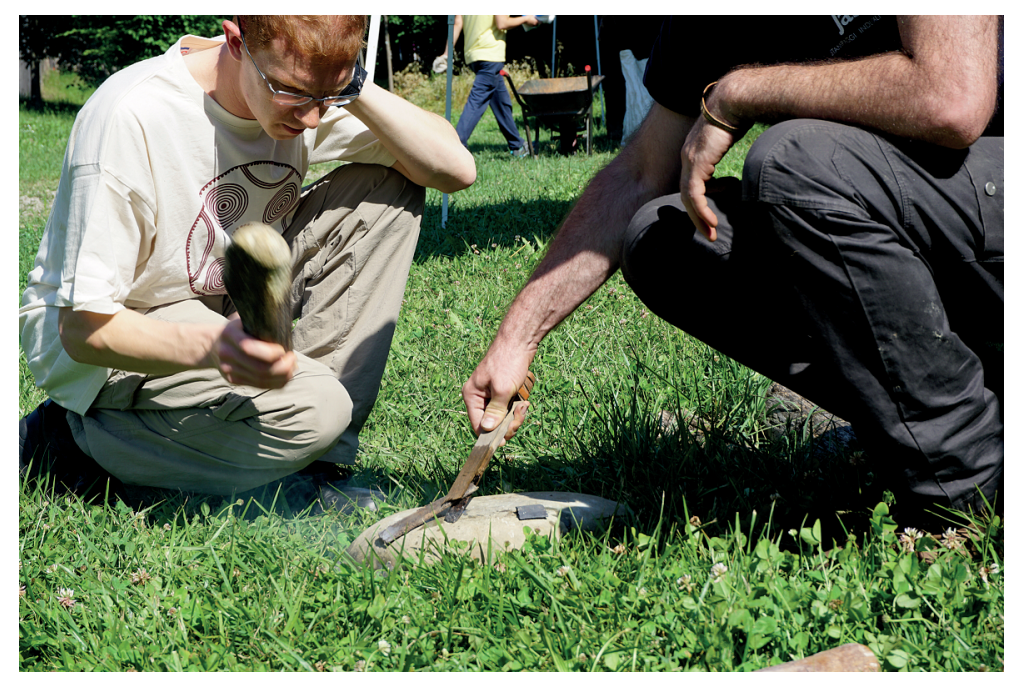

Fig. 3.18: Matthew Knight experimenting with heating and breaking bronze objects. Photo: courtesy Matthew Knight.

There are in theory plenty of ways you can set about breaking a bronze, or at least putting it out of use. The archaeological record is clearer about some of these than others. There are plenty of examples of swords that have been bent double, for instance. Was this what is usually called "ritual killing", or merely to enable it to fit better into a crucible? Were notches along the edge the marks of fighting, or the result of attempts at breaking the weapon on another sharp object? What about the twisting of a weapon? Why do so many swords lack their hilt - is it just a weakness of design, or an intentional snapping of the handle from the blade, as it were an emasculation of the power of a special weapon? These, and similar questions relating to other classes of object, are those that were the object of enquiry in this piece of research, now finding its way into print.

I mention this work because it is one of the most original enterprises on bronze deposition to come out of recent times, and will, I believe, change the way we look at bronze hoards. Even without it, we have moved on from a simple functional explanation of hoards to something rather more nuanced - even though when we are asked what hoarding was all about, we still struggle to convince a layperson that we really know what we are talking about. 


\section{Objects and persons}

Where do we see objects from the ancient past, other than on the pages of scholarly publications? The answer is simple: in museums, where we see the past presented to us as a commodity, usually in static form. But that brings us to a different aspect of our treatment of artefacts: the critical gaze. Michael Shanks and Christopher Tilley wrote in 1987 of "The artifact transformed into an object in commodified time" in a critique of how museum displays work (Shanks \& Tilley 1987/1992, 69 ff., Chapter 4). Objects are divorced from both their ancient context, and also from their modern archaeological context; the observer views them in a distanced way as commodities for learning, potentially as appreciation for their aesthetic quality; but also of course for a kind of disinterested, unengaged promenade that is typical of many, if not most, visitors. Only the original excavator can feel the excitement of experiencing the newly discovered object for the very first time (as most of us who have worked on excavations have done at some point), but modern display technology has the potential to bring that excitement to even the casual visitor.

Much has been written in recent years about how material objects interact with us human beings; it is said that we make objects, but in turn they make us - this is the argument for "entanglement" that Ian Hodder, among others, has put forward (Hodder 2012). The wrist-watch and the motor car are favourite examples of this, since while they are created by us they become an integral part of us and the way we regard the world. What about objects from the ancient past? Hodder referred as long ago as 1990 to his relationship with Çatal Höyük (Hodder 1990, 20): how each brings each other into existence - he meant of course that the site could not exist without his study of it, nor his academic life without the existence of the site he was studying. We could follow the same argument with objects, especially if we wish to consider their life histories.

In considering the relationship between people and objects, one aspect I have so far ignored is the production of those objects - in some ways the most crucial aspect of all. I shall not go into the specific technological processes involved; that is something that has been discussed many times, and would be the subject matter of a different book. But how a craftswoman or man puts her or himself into the object is a matter of great interest, discussed by several authors in recent years. Joanna Sofaer, for instance, has considered aspects of design and creativity in the making of Bronze Age pottery in east-central Europe (Sofaer 2015; 2018); with Lisa Bender Jørgensen and Marie Louise Stig Sørensen she has considered the same aspects in the context of textiles and metalwork as well as pottery (Bender Jørgensen et al. 2018). Particularly important in a Bronze Age context are discussions of craft production and skill in metalworking, and 
here the work of Tobias Kienlin, Maikel Kuijpers and Heide Nørgaard are very important (Kienlin 2008; 2010; Nørgaard 2015; 2016; Kuijpers 2018b; 2018a). While Kienlin focused on the relationship between the technological and cognitive aspects of metal production, Kuijpers has considered the implications for metal production of the role of specialization and acquiring the necessary skills to become a true craftsperson, drawing attention to particular tricks in the production of (among other things) Early Bronze Age flanged axes. Nørgaard has considered the Early Bronze Age metalwork of the Nordic region, paying especial attention to ornaments and producing a subtle analysis of the relationship between technological aspects of metal production and craft skills and tricks. These works have provided an entirely new approach to the question of metal production, which has traditionally been concerned above all with the nuts and bolts of metallurgical technology. They affect all the examples I have introduced above, especially where particular tricks of manufacture or repair are concerned, and these deserve fuller consideration than I can provide here.

\section{Coda}

Returning to the Balkåkra drum, can we add to the life history of this extraordinary object in the light of the considerations I have outlined? Can we imagine it being observed and admired by a traveller from northern lands in the centre of the continent, followed by a ceremony of gift-giving in which precious goods from the north - such as amber - were presented to the southern host, and the drum being given in return? One hopes that the thrill of receiving it outweighed the obvious disadvantage of transporting it home - rather like being given books at conferences for which you have to pay extra at the airport as your bag is overweight. The recipient was no doubt proud of his or her acquisition, whether or not he knew what to do with it. After all, it would have made a wonderful addition to the lur orchestra that was part of the musical scene in Scandinavia in the Late Bronze Age - so perhaps we should imagine the blast of the trumpets accompanied by the banging of the drum in a way that previously no one in Scandinavia could have imagined, one hopes a tasteful way. ${ }^{3}$ Objects in the Bronze Age did indeed have a life.

As I and several other commentators have pointed out, this can only result in a view of the prehistoric past which treats it essentially as a kind of history. Artefacts are one of the prime sources of archaeological information, whether

3 One must admit, however, that the true function of the object is unknown. 
found many years ago or last year; a detailed knowledge of them is essential for any kind of reconstruction that will find wide acceptance. This does not mean that the study of artefacts has to descend into sterile typologising, though typology has its place in archaeological study; the crucial thing is to use typologies in such a way as to be able to derive meaning from them. If they are not to become mere lists, we need to treat them as bearers of significant information on those who made and used them. 